\title{
ВЕРБАЛНА РЕПРЕЗЕНТАЦИЈА КОНЦЕПТА ХРАНЕ У СРПСКОМ ПРИЗРЕНСКОМ ГОВОРУ
}

Вербална репрезентација концепта хране на језичкој слици света српског призренског говора манифестује сегмент традиционалне српске културе у Призрену који се односи на основну егзистенцијалну сферу свакодневног живота и једну од фундаменталних категорија стварности. Истраживање се заснива на речничком корпусу Збирке речи из Призрена Димитрија Чемерикића, који детаљно и поуздано сведочи о позицији концепта хране у језичком сазнању призренске језичке личности с почетка 20. века. Примарни задатак је идентификација одговарајућих когнитивно-смисаоних компоненти и културних чинилаца који учествују у образовању вредносног и информационог садржаја концепта хране а испољавају се у језичком знаку којима су фиксирани на језичкој слици света српског призренског говора не само као когнитивне структуре већ као есенцијални елементи призренске културе. Циљ рада је екстраховање лингвокултурних особености језичке концептуализације хране у српском призренском говору преко језичких јединица које попуњавају концептуално поље храна реконструкцијом терминосистема са идентификационим семантичким обележјем 'храна' који формом и садржајем одражава моделе поимања хране у језичком сазнању призренских Срба и културу исхране у старом Призрену и у којем се експлицитно испољавају специфичне лингвокултурне црте као и језички и културни елементи оријенталне гастрономије под чијим се утицајем вековима формирао.

Кључне речи: концепт храна, српски призренски говор, лингвокултуролошки приступ.

Лингвокогнитивни систем кулинарства сваког народа је сложени семиотички, културни и когнитивни феномен, историјски формиран на основу поимања хране одређеног етносоцијума и детерминисан историјским, социјалним, сакралним, културним представама о храни и временским фактором. Појам хране и у вези са њим гастрономски дискурс функционишу у концептуалној сфери као особит концепт који се вербализује лингвистичким ознакама - номинацијама намирница, јела, процеса припреме, обедовања. Концепт хране и његова језичка интерпретација представљају комплексан ментални конструкт у чији састав улазе одговарајући појмови,

\footnotetext{
${ }^{1}$ tanja77nis@gmail.com
} 
представе, сазнања, приоритети, стереотипи, субјективна оцена, рефлектујући специфику менталитета говорника и њихов поглед на свет, систем социокултурних односа и веза, традицију, обичаје, веровања и начин поимања стварности конкретне говорне заједнице. Стога, концепт хране, као један од централних фрагмената језичке слике света, садржи универзалне елементе схватања хране истовремено експлицирајући етнокултурне специфичности. ${ }^{2}$

Лингвокултурни спецификум концепта хране у језичком сазнању српског народа испитаћемо на примеру кулинарског терминосистема једног српског периферног говора на Косову и Метохији и испитати модел његовог формирања у мултиетничкој средини и под снажним страним језичким и културним утицајем. Језичка и културна интерференција упечатљиво се испољавају у лексичком систему српског призренског говора, посебно у оним сегментима који попуњавају централну зону дијалекатске слике света. Такав фрагмент језичке стварности јесте концепт хране, чија је вербална репрезентација фиксирана у Збиричи речи из Призрена Д. Чемерикића. Чемерикићев речнички корпус доноси мноштво језичких чињеница које детаљно и поуздано сведоче о позицији концепта хране у језичком сазнању призренске језичке личности с почетка 20. века, предочавајући слојевитост, садржајност и богатство његовог израза и садржаја, као и језичке и изванјезичке факторе који су утицали на његово обликовање. Чемерикићеви гастрономски и етнографски записи у великој мери осветљавају традиционалну културу исхране, значај појединих врста хране у свакодневном животу и њену функцију у обичајно-обредној пракси. Аутор често исписује читаве рецептуре припреме јела, даје информације о томе којим су приликама и ситуацијама поједина јела намењена, тако да Чемерикићеви наводи потпуно и поуздано осликавају аутентичну призренску кулинарску традицију и пружају могућност реконструисања лингвокултурних особености гастрономске слике старог Призрена, преко које долазимо до сазнања о начину живота, обичајима и менталитету Призренских Срба.

Примарни задатак је идентификација одговарајућих когнитивно-смисаоних компоненти и културних чинилаца који учествују у образовању вредносног и информационог садржаја концепта хране а испољавају се у језичком знаку којима су фиксирани на језичкој слици света српског призрен-

\footnotetext{
${ }^{2}$ Концепт хране као фрагмент језичке слике света активно се проучава у руској лингвокултури (Генадијевна, 2006; Ермакова, 2011; Борисова, 2013; Боваева, 2012; Јуј, Головња, 2014; Антјухина 2015). Лингвокултуролошки приступ кулинарској терминологији актуелан је и у српској науци о језику (Марчета, 2016; Марчета 2017a, 20176). На српском језичком простору детаљније је испитана култура исхране и обредна пракса у Војводини са језичког и етнолошког становишта (Милорадовић (ур.), 2011, 2014), лексика кулинарства у појединим војвођанским говорима (Радовановић 2011,2013$)$ и војвођански кулинарски терминосистем (Мирилов, 2016). Кулинарска лексика у савременом српском језику најпотпуније је описана у докторској дисертацији Д. Радоњић (Радоњић, 2017).
} 
ског говора не само као когнитивне структуре већ као есенцијални елементи призренске културе. Вербална репрезентација концепта хране на језичкој слици света српског призренског говора манифестује сегмент традиционалне српске културе у Призрену који се односи на основну егзистенцијалну сферу свакодневног живота и једну од фундаменталних категорија стварности, рефлектујући лингвокултурне специфичности призренског социјума прве половине прошлог века. Циљ рада је екстраховање лингвокултурних особености језичке концептуализације хране у српском призренском говору преко језичких јединица које попуњавају концептуално поље храна реконструкцијом терминосистема са идентификационим семантичким обележјем 'храна' који формом и садржајем одражава моделе поимања хране и пића у језичком сазнању призренских Срба, однос према јелу призренске језичке личности, културу исхране у старом Призрену, историјске, културне и језичке утицаје под којима се обликовао и развијао, који су детерминисали његове специфичне црте истовремено га ситуирајући у шири балкански контекст.

Концепт хране може се описати као структура, у чијем су језгру смештене синонимске ознаке са општим значењем ,храна / јело“ (овом приликом пиће нећемо узимати у обзир) и микроконцепт хлеб

Прехрамбени производи спремљени на одређени начин да се могу јести појмовно се региструју као храна, односно јело. Идеографска изнијансираност поимања онога што се једе, што служи као храна пресликава се на лексичко-семантичком плану у виду парадигматских односа међу лексичким ознакама за појам хране / јела. Појам хране обухвата намирнице биљног и животињског порекла које служе за јело, у сировом или термички обрађеном облику, и у српском призренском говору означава се лексемом рана. Она је у синонимском односу са јединицама којима се именује припремљена храна, али истовремено испољава извесну надређеност у односу на остале чланове синонимског реда због општости семантичког знака 'оно што се једе,' што је рангира на хиперонимску позицију. Значењски јој је еквивалентна турска позајмљеница е́рзак, која обједињује појмовне вредности хране и јела. Јело се концептуализује као припремљена храна и у Призрену се вербално реализује лексемама јело, ма́нй'а и манц’а́льк (Је́ло и́маш, пи́ло и́маш, обу́кло и́маш, е́ што о́ч'еш ви́ше; Јефти́на ма́ни'а несла́на; Од је́не масл'и́нке ма́нй'а не би́ва) ${ }^{4}$.

\footnotetext{
${ }^{3}$ Традиционалној естетској култури хлеба посвећен је зборник радова (Жунић (ур.), 2010).

${ }^{4}$ Јело се вари (Ви́ди, девојко, ва́рен л’и је ве́ч'e та́j па́сул. - Ста́ро је за́p ме́со, па се те́шко ва́ри), готви (Ма́ти је у ку́ч'y, го́тви ру́ч'ек. - Кад сти́гоше о́ни, ми́ две́ готве́смо веч'е́ру. - Са́ма меси́ла, са́ма готви́ла, са́ма ми́ла судо́ве), спра́л'а (Спра́л'а ру́ч'ек). Када домаћице храну зго́тве, уго́тве, спра́е, постављају со́фру „обед“, дем. софри́ч'e (Викна́ше га док бе́ше на códpy; Ч'е ни ту́ри је́но софри́ч'e да преку́симо). Породица седа за трпезу према утврђеном распореду - На со́фру му́жи се́диф у ба́m, а ми́, же́не и де́й, седи́мо на дно́ со́фре. Баш је
} 
Култура обедовања у Призрену била је на високом нивоу. Стари При-

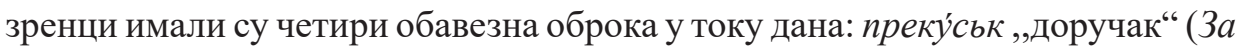
преку́ськ ч'емо попа́py и сире́ъе), руич'ек „главни дневни оброк“ (За ру́ч'ек и́мамо ра́сол-ме́со. - У ъи́ сва́ки дьн а́ руч'ке́ви, а́ веч е́ре), о́бед „оброк између ручка и вечере“ (За о́бед ч'е́мо л'е́ба и сире́ње), веч’е́ра „вечерњи оброк“ (Веч’е́ра ми је гото́ва. - Би́л'е смо на веч'е́ру). ${ }^{5}$ Оброк (та́ксит) завршавао се десертом са општим називом посла́дьк (A: Шmó сте има́ле за посла́дьк? Б: Аляу смо има́л'e). Истом лексемом означава се и завршетак обеда бољим комадом меса (Óвој па́рч’e ме́со сьм остайја да посла́дим веч'е́ру. - Еве ти о́вај мрвва ме́со за посла́дак).

У средишту концепта хране налази се микроконцепт хлеб, са слојевитом вербалном интерпретацијом на призренској језичкој слици света која манифестује традиционално поимање хлеба као основне животне намирнице, што се потврђује низом јединица за означавање различитих врста хлеба које су користиле у свакодневној исхрани старих Призренаца и оних који су се справљали у обредне сврхе и којима је приписивано симболичко значење, као и субјективним односом говорника према овој намирници. Бројност лекичких ознака и денотативно-конотативни садржај упућују на закључак да је хлеб у фокусу менталног лексикона колектива као елемент физичког и духовног опстанка човека. Елементарни значај хлеба у исхрани и његову доминантну позицију у језичком и културном сазнању потврђује метонимијско значење лексеме л'еба. Општи назив за печено тесто од брашна (најчешће пшеничног), воде и квасца, које је основа традиционалне призренске софре, преноси се на остале хранљиве компоенте оброка у јединственој појмовно-семантичкој реализацији „оброк, јело, храна“ (Тьмьн се́досмо да једе́мо л'е́ба, те́ке припуца́ше пу́шке. - Апо́ве узи́мам је́не пред л'е́ба, а дру́zе по л'е́ба по́сл'e). Номинационо језгро концепта чини језичка ознака л'е́ба комплетним садржајем (Што до́ч'ека црини, да је ácpem за је́но кома́ч'е л'е́ба. - Има́ло је два́ ненач'е́та л'е́ба. - А л'ебо́ве неч'áy да ми се повра́тиф. - Ма́mи је у ку́ч'y, размесу́је л'ебо́ве. - За преку́сак ч'е́мо л'е́ба и сире́ґе). Однос призренске језичке личности према овој намирници очитава се у деминутивно-хипокористичним облицима л'е́бац / л'е́бъи (Изе́ди и то́ј кома́ч'е л'е́пц̧а; Оіч'еш маіло л'еіпц̧а да ти даідем?) и л'еіпч'e

почасно место за трпезом намењено домаћину и старијим мушкарцима. Гостима се указује посебна част местом у прочељу, посебно важнијим званицама (Ку́му је ме́сто у ба́m. - Го́л'ем че́c ми уч'ини́mе, тури́mе ме у ба́m. - Се́дни у ба́m, ӥли́и'е си ни). Непоштовање етикеције седења велика је срамота за домаћина (Ку́ку од страмо́mе, го́ста да ту́риф на днó со́фре).

\footnotetext{
${ }^{5}$ Мушкарци су често одлазили на вечере са организованом седењком - акша́мльк (Оти́ша на акша́мльк у Му́са ефенди́је. - Кол 'и́ко акшамлька изе́ја о́н сьс мр́сни). Посебну лингвокултурну вредност имају лексичке јединице довршал'и́и и дожетви́й, којима се денотира вечера нонакон вршидбе, односно након жетве коју домаћин приређује радницима. Ове језичке ознаке чувају информацију о специфичном посленичком обичају у околини Призрена и преносе народно искуство колективног рада и заједничке трпезе као награде.
} 
(Сваіка умесиіла по јеіно л'еìnч'e; На фуірну ку́пи и је́но л'е́nч'е шеспа́рч'e) и у устаљеним радњама у вези са хлебом које имају своју сакралну симболику (Од софре не ваља да се дигне неначет хлеб. Ако се на софру ставља начет хлеб, начета страна треба да буде окренута ка столу. Кад комадић хлеба падне на земљу подигне се и пољуби), што указује на егзистенцијално суштински значај ове намирнице. Функционална искоришћеност домаћег назива у односу на синоним из турског језика е́кмек језичка је чињеница која сведочи о дубоко укорењеној словенској традицији у призренској материјалној и духовној култури. Потврду налазимо у низу именовања за врсте хлеба по диференцијалним знацима:

'врста брашна': коломбо́тњи л'е́ба, коломботњи́йа „хлеб од кукурузног брашна, проја““ (Коломбо́тьи л'е́ба о́ни ви́каф про́jа, а ми́ га ви́камо коломботьи́ия), со́мун, си́мит „хлеб од белог пшеничног брашна“;

'бесквасни хлеб': карь'шьк ,пшеничног и кукурузног брашна, продаје се у пекари“" (Ки́пи му је́н карь́шьк, па нека и́де у ло́jзе. - Ми́ не купи́јемо карьшьие, купу́јемо сому́не), пекси́мит „двопек“.

'облик хлеба': пога́ч'a „округао и пљоснат хлеб“, барени́й „хлеб од пшеничног брашна и масти (масна погача)“ (Барени́ца не́ ми се погоди́ла) $)^{6}$; со́мун „округао хлеб од пшеничног брашна који се продаје у пекари“, си́мuт „врста малог округлог хлеба од белог пшеничног брашна“, сими́ч'e, топл'и́ja „врста симита четвртастог облика, умешена са маслом“.

'место израде': домаћи (који се меси код куће) - погач'а, барени́ияа, коломботьи́й, колач', кра́вај „парче теста што преостане приликом мешења погаче“ (A: Jádна јá, ócmade ми је́н кра́вај од погáч'е. Б: Испе́ч'u га у супра́шку), крава́јч'e „парче теста од којег се развлаче коре за питу“" (Јо́ш ова́ј два-три́ кравајч'е́та да разви́ч'ем. - Узи́мај по́гол 'е́ме кравајч'и́ч'u за ту́j гол 'е́му тепси́jу); пекарски (који се продаје у пекари) - со́мун, си́мит, ока́ник (За сва́дбу поруч'и́ја сто́ окани́ка л'е́ба. - Те́ј окани́це што остана́л'е да даде́мо у иркву за сироти́њу), карь́шьк, пи́та, пита́рка „лепиња“.

'обредни' - ко́лач' „нарочити хлеб (са украсима) за одређене празнике и обреде“; ко́лач сла́вски (Меси се освештеном водицом неколико дана пре славе. Меси га старија жена. Уз колач се меси и пречиста - поску-

\footnotetext{
${ }_{6}^{6}$ „Бареница (масна погача) спрема се на следећи начин: замеси се тесто са кључалом водом, мало посољеном, коме се дода потребна количина масла или масти. Тесто се умеси, обликује у погачу ипече се у тепсији под сачем или код пекара. Као посластица се служи тако што се испечена масна погача издроби на ситне комаде, па се они прелију врућим маслом или машћу, ставе се под врућ сач да се пропрже. Може се посути ситним шећером или сиром“ (Чемерикић).
} 
pa, која се ставља на колач када се сече. Месе се још и погача за под колач и пет поскура за цркву); л'етури’ú ja, Хлеб који се меси о неким црквеним празницима, славски колач (Омеси́ла сьм л'етури’ије за у циркву).

Од старог хлеба правила се попа́pa (За преку́сак да напра́uмо попа́py сьс сире́ґе).

Идеографска слика хлеба у свести старих Призренаца садржи значењске елементе 'пшенично брашно', 'кукурузно брашно', 'тесто', 'мешење', 'печење', 'пекара', 'позитивна субјективна оцена', 'обред'. Даља разрада микроконцепта усмерена је на особине хлеба и фазе у процесу његове припреме.

Централну зону концепта попуњавају намирнице и поступци у кулинарској обради намирница. Основне намирнице које су се користиле у призренској кухињи почетком 20. века су житарице, масти, јаја, млеко и месо.

Прерадом житарица добија се брашно, а у призренским мутвацима онога доба за мешење је коришћено коломбо́тњо, ржа́но и ч'ени́ч'но бра́шњо (Остана́ло ни са́л коломбо́тњо бра́шњо, ч'ени́ч'но смо доспе́л'е. - Да изме́шамо, мо́ри ма́ти, объдва бра́шња). За припрему колача користило се ,најфиније бело пшенично брашно“- нише́сте. Ориз „пиринач“ употребљавао се као главни састојак разноврсних јела (И у При́зрен поч е́ја да се се́је о́риз. - За ру́ч ек сьм пристави́ла о́риз);

У исхрани Срба Призренаца заступљене су масти (ма́сло) и биљног и животињског порекла. Кувало се претежно на свињској масти - сви́ғско ма́сло, ма́сло мр́сно, ло́j (,„лој су користили и Срби и муслимани у Призрену. Куповали су сиров лој, топили га и разливали у погаче и охлађене вешали о таване" (Чемерикић)). Карактеристичним традиционалним поступцима обраде млека добијане су млечне масноће: ма́сло „млечни производ који се издваја из млека бућкањем“; муч'ени́ца „масло добијено мућењем слатког и киселог млека у бучки“; ка́јмак „скоруп са куваног млека, који се не соли“. Чемерикић наводи да су се у Призрену разликовале ,две врсте масла: масло нетопено или масло пресно, онакво какво се добија из млека, и масло топено, истопљено и припремљено за употребу“ (Чемерикић) (Дадо Симе за масло паре (из тефтера). - Пи́та без ма́сла не би́ва). Лексема масло појављује се као главна компоненте двочланог назива дрве́но ма́сло којим се именује биљно уље (У́зии и је́но сто́ дра́ма дрве́но ма́сло).

Млеко (мл'е́ко) и јаја (јájųe/ јáju̧a) суштинске су прехрамбене сировине (Си́мит је́ла, пре́сно мл'е́ко пи́ла. - Да́вај му неваре́но мл'еко од магари́ие, па ч'е му прой'е гол 'ем ка́шал'; Са́ндо, да́j ми то́ј крше́но ја́јизе да зач 'и́ним ч’óрбу? - По́што у́зе ја́јu̧а?)

Из Чемерикићевих записа сазнајемо да су „Срби у Призрену до Првог светског рада углавном јели овчетину, јагњетину, младу јаретину и 
браветину, а говедину ретко. Говедина се користила за исхрану по селима, па се и клање говеда вриило за пазарни дан - среду“. У Збирии су забележене две лексеме са општим значењем, ,делови закланих животиња и живине (као храна)»: ме́со (Гове́ико мі́со) и аугментативно-пејоративна варијанта меси́ште (Закла́л'е смо бивол 'и́иу, па му́ка да те уфа́ти од тол 'и́ко меси́ште). Месо ситне стоке (овце, козе, свиње, односно јагњетину, јаретину, прасетину) Призренци су обично куповали на четвртине - на че́рек (Све́ на чее́л'е ч'ере́це што се купува́ло ме́со у њи́. - Орта́ч'ки купи́смо је́но jázње па га подел 'и́смо сва́кому по је́н ч'е́рек), а месо располућене животиње - лубину ${ }^{7}$ су сушили и користили за припрему разних јела (Ва́j луби́на ка да је од ко́зе. - Ми́то, до́и'u на ру́ч'ек у на́с, и́мамо па́сул' сьс луби́ну). При куповини се веома водило рачуна о квалитету меса, па се бирало најфиније месо - ту́л', тул 'úųа, тула́сто ме́со „кртина“ (Ма́ти, да ми ми́ико тул'и́иy, не́ч ' прети́ло; Са́мо тула́сто ме́со у́зни), а избегавало кока́ло „месо лошег квалитета са пуно костију“ (Гл'е́дај што купу́јеш, не́мој да ми ку́пиш кока́ла) и прети́ло „масно месо“ (Ку́пи је́ну о́ку ти́л’, не́мој да ки́пиш прети́ло. - За јани́ју по́арно је претило зе ту́л').

Повртне културе које су се узгајале и користиле у исхрани уобичајене су за ово подручје - лу́к „бели лук“ (Стучч’u лу́к. - Лу́к ти у о́ч'u), кромид „црни лук“. (Исе́ч'и кро́мид. - Доне́си ми два-три́ гол'е́ма кроми́да), пра́с „празилук“ (Ку́nи пра́с), ко́мпир „кромпир“ (За вече́ру да сва́римо ко́мпир. - Је́фо, доне́си ми два-три́ компи́ра), ку́пус / купуз „купус“, па́сул' „пасуљ“ (Светого́рски па́сул'. - По́сьн па́сул'. - У Џ'аковь́чку найју па́сул' сла́бо роди́ја ви́j годи́ну), пасул'и́иа „боранија“ (Што купи́ја је́ну пасул'и́иу, жу́та ка дуккат), ба́кла „боб“ (Ре́кните што ч’е́те за ру́ч'ак, о́ч'ете л’и да ви зго́твим баклу?), патл'и́и'ан „парадајз““(бе́ја патл 'úи'ан; ирвен патл'и́и'ан са сортама: јабу́кар „врста парадајза чији је плод у облику јабуке“, месе́ч 'ap), л'ути́ка ,паприка“ (са сортама: подврка „паприка чији плод расте под самим врхом биљке“ (Де́ си купи́ја те́ј подвр́ке?), пумпула́јка / трумбула́јка л'ути́ка / трупул'áста „крупна паприка, бабура“ (И пумпула́јка мо́же да иско́ч'и л'у́ma. - Купи́ја скапа́не пумпула́јке. - Да си ми купи́ја и ко́jу л'ути́ку трумбула́јку)), крастави́ца, краста́вч'е „краставац“" (Бостани'и́је прода́вау крастави́ие. - Одво́j те́j краставч'и́ч'и да ту́римо у туршијју), ардь́ква „ротква“ (Испеч'и му јену ардькву, па му дај да изеде), модьр патл'иц'ан „Плави патлиџан“ (Испе́ч'u и је́н мо́дьр патл'и́и'ан. - Ту́ри у турши́ју и мо́дре патл'ии'а́не). Са истока су усвојене неке врсте поврћа које нису типичне за наше поднебље, као што је леблебија. Лексичка експонираност сланутка - л'ебл 'еби́ja / ебл'еби́ja / јебл'еби́jа, на́ут, ч'úч'ер, бо́бо (у дечијем говору) показује позицију коју ова оријентална намирница има у исхрани и

\footnotetext{
7 „Лубина је половина заклане ситне домаће стоке, располућена по дужини, па без главе усољена и осушена на диму“ (Чемерикић).
} 
кулинарској свести Срба Призренаца. Печено или пржено зрно наута јело се као посластица или као мезе уз ракију, кувало се у јелима, користило као додатак кафи (Деца́мма доне́ја кӥрӥзӥм и л’ебл'еби́jу).

Утицај оријенталне гастрономије огледа се и у широкој примени бостана, као и у техници конзервирања лубенице, диње, бундеве. Лубеница - лубени́иа, лубе́нч'e омиљена је сезонска посластица старих Призренаца (За ру́ч'ек да исе́ч'емо је́но лубе́нч 'е. - Те́ј две́ лубенч'е́ти пу́шти у бу́нар да се ла́диф. - Де́ си купи́ја те́ј лубенч 'ú 'u? - Узе́ја лубенч 'úч 'е за турии́ју). Гајене су различите, оријенталне врсте лубеница: царигра́дска / белокорка „врста лубенице са белом кором“, режењи́ја „врста лубенице чија је кора ишарана у виду режњева“, си́бре лубени́ц̧а. Такође је и диња (ди́њ $а$, ди́њч’e) веома заступљена на традиционалној призренској трпези (У ба́шч'y ни ни́кла је́ на ди́ньа - Купи́ја је́но бастрал'и́ја ди́ғч'е. - За ручч'ек да исе́ч'емо те́ј две́ дињч'е́ти ито и́мамо. - Диззај се да ту́римо те́j динч'úч'u у туршиију). Тиква (тиква, тиквиіч'e) је термички обрађивана на разне начине (кувана, печена, као џем - ре́ч'ел'), а најчешће је коришћена врста ба́л каба́zu ,тиква дугуљастог облика која садржи доста шећера“ (Купи́ја сьм ба́л каба́zи за ре́ч'ел'. - Да испеч е́мо ту́ј ба́л ка́баги за веч 'е́ру).

Интересантно је да је да су се у призренском кулинарству оног доба, под утицајем турске кухиње, интензивно користили различити зачини, који су се сем за побољшање укуса употребљавали и у терапеутске сврхе. Са хиперонимима зач 'úн и исиот (Ту́ри ми ма́ло ви́ше иси́от), најфреквентнији су: сол, со́л бе́ја „ситна кухињска со“ (Сол ва́л'а да се ку́nи, са́мо јо́ш дватри́ груме́ґ а што и́мамо), ал-л'ути́ка, „ситна алева паприка произведена у фабрици“ (Ту́ри и ма́ло ал-л 'ути́ку), цииа́нска л 'ути́ка ,врста туцане паприке коју су домаћице саме спремале од црвене печене паприке“, караби́бер „црни бибер“, магдо́наи „,першун“, ,ана́сон „,анис“ (Јо́ш ана́сон да ту́рим nа је гото́во), ч’úмнон „ким“, дарч’и́н „цимет“, кара́мфил' „каранфилић“.

У категорији воћа у Чемерикићевом материјалу доминирају називи за крушку (13), што имплицира да је крушка прототипична врста воћа, односно воч 'ка у ондашњем Призрену: бени 'арка (Кру́шка бенй 'а́рка не́ ми се уфати́ла, осуши́ла се), боздова́нка / боздога́нка „врста крушке обликом налик буздовану“ (Боздова́нка тра́жи ме́сто, о́на не́ч'е сву́д. - Де́ си на́ша теј боздова́нке? - Боздога́нке сла́бо роди́л'e), водења́ч'a „врста сочне крушке“ (Водења́ч'a не́ ни роди́ла ни кол'и́ко да се оруч'имо), запира́ч'ка „врста крушке ситнијег, округластог плода““ (Гл’е́дај, ку́nu л’е́nе кру́шке, не́мој да кýnиш запира́ч'ке) ${ }^{9}$,

\footnotetext{
${ }^{8}$ „Бени'арка је врста крушке која је добила назив по презимену породице Бенџар, који су је узгајали у свом винограду. По једној крушци из винограда у Призрену је настао израз бениарова крушка. То је крушка која је расла на ивици винограда, поред којег је водио пут, па су је пролазници брали као да је њихова. Овај израз значи нешто што свако може узети и разносити по вољи (Ej, ви́, не заде́вајте тој, не́је то́j бенц’а́рова кру́шка)“ (Чемерикић).

9 „Плод ове крушке је опорог укуса, па се једе скуван. Назив је добила јер при једењу „запире“ у грлу. Да би стасале, држе се дуже у слами“ (Чемерикић)..
} 
зејтињáчa „врста крушке крупнијег, зеленог плода“, ини’ и́рка „врста крушке ситник, накиселих плодова“, јеч'менка „врста ситне крушке која сазрева кад и јечам“, калуц’е́рка „врста крупне, сочне крушке“, лубенича́рка „врста румене, округле крушке“, поло́шка „врста округле мале крушке, која се једе само кувана“, прсте́нска кру́шка „врста округле, крупне, сочне крушке која рађа у касну јесен, ч 'е́кл'ик-бу́mu „врста ситне крушке, калуђерке“, дивл 'áч 'ка „самоникла јабука или крушка“ (И́мам ни́јет да кал'е́мим ту́j кру́шку дивл'áчку. - Мла́ди је́деф ди́вл'ач 'ке, а на ста́ри трнер зу́би).

По лексичкој заступљености у лексикону следи јабука (са шест номинација): бузл’и́ја „врста ситних јабука које кад сазру постају прозрачне попут

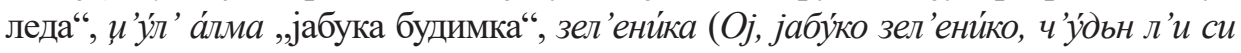
ро́d роди́ла (нар. песма)), јабу́ка дивл 'а́ч'ка „врста ситних јабука које се не једу док потпуно се сазру због чега се чувају у слами“" (Ку́nи до́бре јабу́ке, гл 'е́дај да не́су јабу́ке дивл 'áч'ке. - У ло́јзе ми ни́кла је́на јабу́ка дивл 'а́ч 'ка), петро́вка „врста јабуке која сазрева у јулу, око Петровдана“" (И́ма у ч’арии́ју јабукке петро́вке), шербе́тка „врста ситне слатке јабуке“.

Са далеко мање хипонима јављају се ил'и́ва: топери́za „врста крупих округлих шљива, жуте или зелене боје“ (Једе зел'ене топериге), и'анариіка „врста шљиве чији је плод округао, црвенкасте боје“, меч 'ера́ча „врста шљиве пожега“ (И́мам са́мо је́ну сл 'úву шеч 'ера́ч'y. - Шеч 'ера́ч'е јо́ш не искоч'úл'е y ч’apuújy); ире́шњ плода која се гајила у Призрену и околини“ (Тáj далбасти́ја ни се осуши́ла. Ву́j годи́ну далбасти́је сла́бо роди́л 'е. - Да́j му ко́ју далбасти́ју да оква́си у́ста. - Ако купу́јеш ире́шње, у́зни са́л далбасти́је), кајсија: зердел 'и́ја „врста ситне и слатке кајсије“, праска „бресква“ (На́ше пра́ске не́ ни роди́л'е ве́j годи́не).

Посебан статус у култури исхране Призренаца има гројзе, у вези са којим је развијен религиозно-симболичан чин „оручивања“: „Код Срба у Призрену је обичај да се бело грожђе не једе пре празника Преображења и пре него што се на тај дан не освети у цркви. Сваки домаћин који има свога грожђа донесе по један сахан у цркву, остави га на олтару и тек пошто га свештеник освешта, куша које зрно (оручи се), нудећи суграђане који немају свога грожђа. Познаници се овако поздрављају: „Оручисте ли се од гројзе? Нека ви је на живот и на здравље!“‘, на шта се одговара: „Да си жиф, и вама да је на живот и здравље, да бог да“". Остатак домаћин носи укућанима да се и они оруче. Црно и црвено грожђе се по обичају не једе пре празника Усековање главе св. Јована. Из овога су изузети болесници, за које ова ограничења не важе“ (Чемерикић).

Стари Призренци конзумирали су средоземне културе: л’и́мон, протока́л', на́p, а нису им биле непознате ни источњачке: урма, и́нц’ир „смоква“, фь'ндьк „пистаћи“, кӥрӥзӥм ,суво грожђе““.

Воће се јело у свежем облику и конзервирало се у виду пекмеза - 
ре́ч'eл', ма́u’'yн. ${ }^{10}$

Наведене намирнице користе се као састојци за припрему разних јела, чији називи попуњавају ближу периферују концепта. У овом домену призренску лингвокултуру одликују јела од меса, јер је ова категорија у кулинарском терминосистему српског призренског говора лексичко-семантички најпродуктивнија. Раслојава се у неколико подгрупа, међу којима су карактеристичне 'месне прерађевине' као начин пастеризовања меса: пастрма „сушено месо“, висмени́ца, „сушена вешалица од меса“ (Ocymúja се ка висмени́ца), бу́мбар „врста кобасице у говеђем дебелом цреву“ (За о́бед да исе́ч емо је́н бу́мбар. - Обеси́сте л’и бумба́ре у о́и'ак? - Бумба́ри јо́ш не́су cýje), со́и'yк „1. кобасица од танких говеђих црева и говеђег меса. 2. ћевап“ и 'оријентална јела од меса' (углавном од јагњећег у комбинацији са поврћем и пиринчом): би́рјан, ,јело од јагњећег меса, пиринча и спанаћа“" (3a ру́ч'ак смо има́л'е би́рјан), капама ,јагњетина кувана са спанаћем, црним луком и машћу, служи се преливена киселим млеком“, капамајани́ја ,јело од говедине, лука, сирћета, зачина и масти; спрема се у земљаном суду који се покрије папиром, пече се у пекариници“; папаз јани́ја „,кувано месо са луком, першуном и уљем“, сарма, ,јело од исецканог меса, пиринча, црног лука, увијено у листове киселог купуса, винове лозе и сл.“, јала́нц’и/ јальни'и са́рма „сарме се не завијају, већ се преко надева ређају листови киселог купуса“, расол-месо ,јјело од киселог купуса и меса“, мисека „мусака““ (За ру́ч'ек ч'е́мо мисе́ку), кьза́ртма „врста јела са пирганим јагњећим месом“, оризме́со ,јело са месом и пиринчем“ (За ру́ч'ек ч’е́мо оризме́со), núл'аф ,јело од пиринча и меса“, та́ва „1. јело од меса и поврћа (зеленог патлиџана, паприка, бамње, црног лука) које се пече у тави. 2. јело од пиринча и овчијег меса“ (Те́j но́zе да ту́римо на та́ву), се́бзе „пиринач куван с црним луком, чиме се пуни кокош која се потом пржи“, ч’ебап „,1. комадићи меса печени на роштиљу, ћевап. 2. ђувеч“, шихи ч’е́бап ,месо исечено на комадиће натакнуте на ражањ, ћевап“, ч’ýpma, ч'yфmuіч'e ,испржена лопица од ситно исецканог меса, црног лука и бибера“, кау́рма ,јело од уситњених свињских изнутрица и зачина“. Јела од рибе нису карактеристична за призренску кухињу.

Специфична одлика гастрономске културе старог Призрена јесу разне врсте пита: колnи́ma „1. пита савијача са сиром. 2. пита са прженим живинским месом која се меси за Беле покладе“ (Колпи́ma не́ ми се погоди́ла дьньс), безгла́вник „врста пите без горње коре“, зел'аник безглавник „пита од зеља без горње коре, заливена киселим млеком и јајима“ (Меси́ла сьм ви зел'а́ник безгла́вник), писпил'úma ,пита од кукурузног брашна са зељем или спанаћем и сиром“ (Писпил'úma не́ ми се погоди́ла. - За веч'е́ру ч'е́мо и је́ну писпил 'úmу), тикве́ник ,пита од бундеве“.

$\overline{10}$, У Призрену се речељ најчешће кува од грожђа и тикава“ (Чемерикић). 
Призренска трпеза није била потпуна без посластице, која је неретко замењивала читав оброк. Направљени од класичних састојака (млеко, јаја, шећер, брашно, маст) и заливени шербетом (сирупом од прженог шећера) по блискоисточној рецептури слаткиши су главни репрезенти локалног кулинарског кода и носиоци етнокултурног спецификума. У култури исхране старог Призрена бла́zо заузима истакнуто место како у свакодневном конзумирању хране (А: - Има́л'е л’и сте и бла́го за ру́ч'ек? - Б: А́лву смо има́л'е. - Пун са́ан бла́zо што изе́де тај изе́ша), тако и у ритуалним активностима везаним за обреде животног циклуса (3а првич'ápe три́ бла́zа: сутл 'újaч', када́иф и тепстешти́je). Поједине врсте колача обавезни су елементи сценарија многих обичаја, при чему превазилазе основну намену, шире појмовни оквир пунећи га ритуалном симболиком. Пригодни карактер призренских делиција резултира семантичком слојевитошћу назива за посластице, који истовремено репрезентују свакодневну стварност и манифестују обичајнообредну праксу старих Призренаца, преносећи информације о начину живота и духовној традиционалној култури говорне заједнице. Етнолингвистичка интерпретација језичких ознака за врсте слаткиша у Чемерикићевом лексикону употпуњује представу о прототипичном јеловнику који у свечаним приликама и о религиозним празницима поприма виши, сакрални смисао, актуелизирајући специфичан културни фон и социјално-етичку значењску димензију, док се у самим именовањима очитава директна лингвокултурна интерференција са турским етносом. Посебан религиозно-обредни значај имају куване житарице са додатком заслађивача (меда, шећера - ше́ч'ер, ч'есме-шеч'ер „шећер у коцкама“, тоз-ше́ч'ер „шећер у праху“), орашастих плодова и зачина: ащýре „посластица од пшенице са медом и орасима коју дервиши на дан задушница деле народу““ (Нактари́je де́л'иф амýpe y Шадрван), ситл'ијач' „пиринач куван са млеком и шећером; обавезно се кувао на празник Спасовдан, када су се млади и стари окупљали око цркве и проводили дан у песми и игри“, зе́рде „пиринач куван са шећером, којем се додаје шафран да буде жут; био је обичај да се на Чисти понедељак излази на брдо, наложи ватра и кува зерде“ (Пошто је ју́тре пра́зник, за ру́чек че ви зго́твим и зе́рде). Обичајну улогу реализују тепсешти́jа „врста колача од брашна, шећера, цеђи и масти, преливен шербетом; служи се у свечаним приликама и да се укаже посебна част гостима“ и тигањи́uе „пржено тесто посуто шећером, уштипак, које се носи као дар невестама и породиљама“. $\mathrm{У}$ уобичајеним ситуацијама на редовном јеловнику служили су се арабанија / раванија (Спреми́ла л'и си ше́рбет да попа́рим равани́ју? - Л'е́по ти се погоди́ла раванија), а́лва (Има́л'е смо а́лву и за веч'е́ру. - А́лва не́ ти се погодила дьньс), кос алва „бела алва са орасима“, тан алва / тана алва / таен алва „посластица од брашна, шећера и сусамовог уља“, бакла́ва „слатка пита с орасима“ (Бакла́ва не́ ми се погоди́ла, бе́ше гу препека фурнай ’újа, вра́z да га изе́де), када́ив / када́иф „врста слаткиша од танких резанаца, 
који се преливају машћу, између слојева ставља се бадем или орах, а печен се прелива шербетом“, кајмач'úна „врста посластице са јајима, шећером и овчијим млеком“ (Деца́мма ч’е́сто ги пра́им кајмач’úну), татл'ије „врста слатких колача, брдарице“, та́тл’и тулу́мба / тулу́мба татл'úje „пржено тесто преливено шербетом“, шеч'ерпаре „врста ситних колача четвртастог облика који се спремају од истог теста као и тепсештије“ (За веч'е́ру сьм cпраи́ла шеч'ерпа́pe), ло́кум „врста ситних колача од теста четвртастог облика, пржених на масти“, локма-щеч’ер „ратлук“ (Ку́пи је́ну кути́ју ло́кмаше́ч'ер), пе́нир-ше́ч'ер ,посластица беле боје“, со́и’ук,,посластица од ораха нанизаних на конац и преливених смешом за ратлуке“, мал'еби́ја „врста сутлијаша“, долду́рма „сладолед“ (Да́j му кој ма́нгьр за долду́рму).

Лингвокултурна специфика концепта хране на призренској слици света дестерминисана је прожимањем словенске и оријенталне традиције кулинарства, што се огледа у избору намирница и њиховом комбиновању, начину припремања јела, одабиру назива за јела, односа према храни и саме културе обедовања, тако да су у старом призренском кулинарском терминосистему фиксирана етничка, социокултурна и лингвокултурна идентификациона обележја и кодирани елементи оријенталне гастрономије под чијим се утицајем вековима формирао.

\section{Литература}

Антјухина 2015: А. В. Антюхина, Еда как форма культурной идентификации, Научно-методический электронный журнал «Кониепт», 8, 246-250. URL: http://e-koncept.ru/2015/65050.htm. 29. 6. 2019.

Бовајева 2012: Г. Манджиевна, Лингвокультурная специффика этнических пищевых предпочтений: на материале глюттонических номинаций калмыцко-, русско- и немеикоязычных этносов. https:/www.dissercat.com/content/ lingvokulturnaya-spetsifika-etnicheskikh-pishchevykh-predpochtenii 29. 6. 2019.

Борисова 2013: Л. В. Борисова, Концепт «пища» в культурологическом пространстве русского языка, Вестник Чувашского университета №, 224-230. https:// cyberleninka.ru/article/n/kontsept-pischa-v-kulturologicheskom-prostranstverusskogo-yazyka 27. 6. 2019.

Ермакова 2011: Л. Р. Ермакова, Глюттоническая номинация в этнокультурном аспекте. 9http://www.rusnauka.com/28_PRNT_2011/Philologia/9_94631.doc. htm27. 6. 2019.

Жунић (ур.) 2010: Д. Жунић (ур.), Традиционална естетска култура: хлеб. Ниш: Центар за научна истраживања САНУ и Универзитет у Нишу.

Јуј, Головња 2014: Я. Юй, А. И. Головня, Репрезентация концепта еда в китайской и русской культурах, Карповские научные чтения:. Вып. 8. Минск: Белорусский Дом печати, 154-162.

Марчета 2016: Ј. Марчета, Кулинарска терминологија у франиуској, италијанској и српској фразеологији. Необјављена докторска дисертација. 
Марчета 2017: Ј. Марчета, Утицај европске културе на језичку слику света говорника српског, француског и италијанског језика (на примеру фразема са кулинарском компонентом). Прилози проучавању језика, 48, 109-125.

Марчета 2017a: J. Марчета, Култура исхране као основа фразеолошког изражавања српског, француског и италијанског народа. Култура 156, 146-159.

Милорадовић (ур.) 2011: С. Милорадовић (ур.), Култура исхране у Војводини кроз обредну праксу. Лингвистички и етнолошки аспект. Нови Сад: Матица српска.

Милорадовић (ур.) 2014: С. Милорадовић, Обредна пракса-речима о храни. На материјалу из српских говора Војводине. Нови Сад: Матица српска.

Мирилов 2016: Р. Мирилов, Кулинарска терминологија Војводине. Необјављена докторска дисертација.

Петровић 1995: С. Петровић, Неки турцизми у српскохрватској кулинарској терминологији. Јужнословенски филолог, LI, 223-232.

Радовановић 2011: Д. Радовановић Д. Из кулинарске лексике Санада и Мокрина. Лексиколгија. Ономастика. Синтакса. Зборник у част Гордани Вуковић. Нови Сад, 227-238.

Радовановић 2013: Д. Радовановић, Српска и румунска трпеза у северном и средњем Банату. Језици и културе у времену и простору 2. Нови Сад: Филозофски факултет, 205-212.

Радоњић 2017: Д. Радоњић, Кулинарска лексика у савременом српском књижевном језику. Необјављена докторска дисертација.

Савељева 2006: О. Г. Савельева, Концепт «еда» как фрагмент языковой картинь мира: лексико-семантический и когнитивно-прагматический аспекты. Диссертации по гуманитарным наукам - http://cheloveknauka.com/ kontsept-eda-kak-fragment-yazykovoy-kartiny-mira-leksiko-semanticheskiy-ikognitivno-pragmaticheskiy-aspekty\#ixzz6CPQ2OExU 27. 6. 2019.

\section{Извор}

Димитрије Чемерикић, Збирка речи из Призрена, http://prepis.org.

Tanja Z. Milosavljević

\section{THE VERBAL REPRESENTATION OF THE CONCEPT OF FOOD IN THE SERBIAN SPEECH OF PRIZREN}

\section{Summary}

The verbal representation of the concept of food in the linguistic image of the world of the Serbian speech of Prizren manifests a segment of traditional Serbian culture in Prizren, which refers to the basic existential sphere of everyday life and one of the fundamental categories of reality, reflecting the linguacultural specificities of the Prizren socium from the beginning of the twentieth century. The linguistic units 
which fill out the conceptual field of food with their form and content reflect the models of understanding food and drink in the linguistic knowledge of the Serbs from Prizren, the relationship towards food in the Prizren linguistic personality and the culture of food in old Prizren. The ethnic, sociocultural and linguacultural identification features are fixed in culinary system of terms, in which we find the coded elements of oriental gastronomy under whose influence it developed for centuries.

Key words: the concept foot, the Serbian speech of Prizren. 